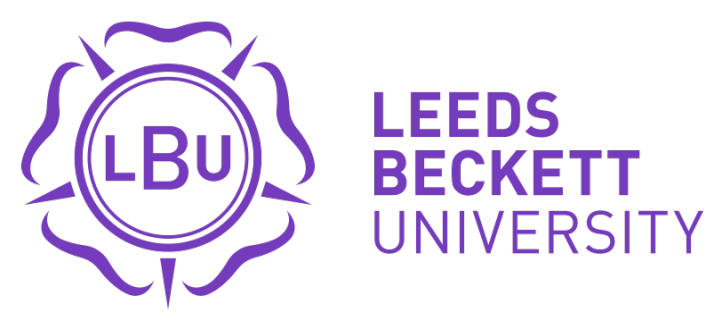

Citation:

Dampier, HC (2016) 'Going on with our little movement in the hum drum-way which alone is possible in a land like this': Olive Schreiner and suffrage networks in Britain and South Africa, 1905-1913. Women's History Review. ISSN 0961-2025 DOI: https://doi.org/10.1080/09612025.2015.1114319

Link to Leeds Beckett Repository record:

https://eprints.leedsbeckett.ac.uk/id/eprint/2067/

Document Version:

Article (Accepted Version)

The aim of the Leeds Beckett Repository is to provide open access to our research, as required by funder policies and permitted by publishers and copyright law.

The Leeds Beckett repository holds a wide range of publications, each of which has been checked for copyright and the relevant embargo period has been applied by the Research Services team.

We operate on a standard take-down policy. If you are the author or publisher of an output and you would like it removed from the repository, please contact us and we will investigate on a case-by-case basis.

Each thesis in the repository has been cleared where necessary by the author for third party copyright. If you would like a thesis to be removed from the repository or believe there is an issue with copyright, please contact us on openaccess@leedsbeckett.ac.uk and we will investigate on a case-by-case basis. 
'Going on with our little movement in the hum drum-way which alone is possible in a land like this': Olive Schreiner and suffrage networks in Britain and South Africa, 1905-1913 ${ }^{1}$

\begin{abstract}
... I want to start a league of men and women together to be called, "The Citizen Franchise League", to work for all forms of enfranchisement, the women and the native, and to resist all attempts to take the franchise from those who have it now. (This is private, don't let it get into the papers till the League is started). If you are too busy, please send the copy of my paper I am sending with this to Dr. Alice Corthorne. Please let me have a line. Our Woman's work will get on much better here if we work men \& women together.

The women here are all far behind. There are three men in Africa who want to see women enfranchised for every one woman. Three men who voted for us in Parliament, have wives who are bitterly opposed to our getting the franchise. The condition of affairs here is entirely unlike that in England. I believe your tactics are absolutely wise and right there. ${ }^{2}$
\end{abstract}

It is glorious how you are getting on with your work in England. It is the women here we have to rouse! and our Women's Enfranchisement League, owing to bad management and wrong starting has done more harm than good, I fear. But among the younger South African women a splendid feeling is growing. I am writing a short article defending the tactics of the Women's Social and Political Union and will send it to the Fortnightly Review and am going to write a paper on the Woman question, in length about like that the pamphlet and am going to have it printed as a small booklet. ${ }^{3}$

Thanks very much for the books, all of which I have received. I have sent out a number of "Votes for Women". I hear the Cape Government are from next month going to take over all the Railway bookstalls in the country which have hitherto been in the hands of the Central News Agency. If we could get them to exhibit "Votes for Women" on the Railway \& other bookstalls, they might easily sell some hundreds a week. I will find out what member of the Government the bookstalls will be under and (if it is not $\mathrm{Mr}$ Burton who is a bitter opponent) I am sure any minister will give permission for it to be sold. Write me a short business letter on what terms the

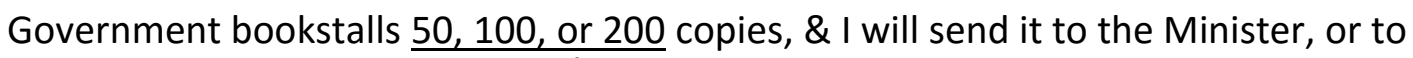
the man he tells me to send it to. ${ }^{4}$

The quotations which form the epigraph to this article are extracted from letters by the South African feminist writer and social theorist Olive Schreiner (1855-1920), to Frederick Pethick-Lawrence, an influential figure in the Women's Social and Political Union (WSPU) through his marriage; his wife Emmeline was the WSPU's Treasurer. ${ }^{5}$ Schreiner's comments usefully highlight her position as at once part of both a local and global women's suffrage movement, as a crucial node in this particular 'imperial network'. ${ }^{6}$ Schreiner was operating as a member of a global women's suffrage movement, partly in that she was corresponding 
with and exchanging ideas and information with Frederick Pethick-Lawrence in Britain, but also that she was planning articles for the Fortnightly Review in defence of the WSPU ${ }^{7}$, receiving and reading batches of books relating to 'the woman question' sent by her friends in the British suffrage movement ${ }^{8}$, and she was arranging for the WSPU's 'Votes for Women' newspaper to be distributed and sold in South Africa. Her comments also highlight the emphasis Schreiner put on the importance of connections, working co-operatively and exchanging ideas within the global movement. Thus she sent Pethick-Lawrence a political paper she had written ${ }^{9}$ to pass on to her friend Dr Alice Corthorn, also active in suffrage work in Britain, and she stresses that it is men and women who should work together: for Schreiner, suffrage work was not women's work alone (perhaps implicitly commenting on Pethick-Lawrence's role in the WSPU).

However, her remarks to Pethick-Lawrence suggest that Schreiner's focus was also resolutely local: she was active in the Cape Colony's Women's Enfranchisement League (WEL), she was writing pamphlets on the 'woman question' for printing and local distribution, and as the first extract from 1909 demonstrates, she was also planning to launch a local 'Citizen Franchise League' to campaign for universal adult suffrage although in the event this was not realised. In addition, while Schreiner was clearly intent on forging links between the South African and wider suffrage movements, she was also acutely aware of the differences between the contexts in South Africa and Britain. She comments that in Britain men are much more politically progressive than women; in South Africa it is women who need to be roused to action; the condition of affairs in South Africa is 'entirely unlike that in England'. And for Schreiner, the most important distinction between the British and South African contexts was of course the question of race. Schreiner was acutely aware of the political complexities this involved, and as I will demonstrate, for her the vote for women should never be prioritised over political rights for the black majority, and nor should white women be campaigning for the vote on the same (racial) grounds as men, with this again highlighted by her 1909 attempt to establish a Citizen Franchise League. ${ }^{10}$

\section{Historiographical context}

Certainly a great deal has been written about the suffrage movement in Britain and the US, but as June Hannam has noted, 'the aims, methods and nature of the suffrage movement worldwide have been overshadowed by the experience of the British and American struggles for the vote'. ${ }^{11}$ Nonetheless, in the last few decades, studies of international suffrage movements have burgeoned ${ }^{12}$, and increasingly 'require us to go beyond the dichotomies that have often contained suffrage histories in the past', particularly the 'dichotomies between the margins and the centre'. ${ }^{13}$ Rather less has been written about the women's suffrage movement in South Africa, with some notable exceptions including the pioneering work of Cherryl Walker and more recent analyses by Pamela Scully and Deborah Gaitskell. ${ }^{14}$ Their work has rightly emphasised the ways in which the suffrage movement in 
South Africa was dominated by white, middle-class, English-speaking women who explicitly campaigned for the vote on the same (racial) terms as men. While black men enjoyed a qualified franchise in the Cape until 1936, this provision was not extended to South Africa's other three provinces with Union in $1910 .{ }^{15}$ Rather than support the extension of the franchise to all South Africans, or campaign for all women to be included in the Cape's qualified franchise (which would have extended the vote to black women who met the relevant property and educational qualifications), following Union the women's suffrage movement in South Africa decided to campaign for the franchise on the same racial terms as men outside the Cape. With notable exceptions like Schreiner, suffragists in South Africa did not envisage political rights for black women at all; indeed as Scully has persuasively argued, white suffragists tended to view black women as 'infantile' and assumed they did not have the necessary 'maturity' to qualify for enfranchisement. Scully suggests that white suffragists in colonial South Africa predominantly based their claim to the vote on ideas about women as nurturing mothers and moral arbiters, qualities which they suggested qualified white women for the franchise, and which would enable them to assist Africans in climbing the 'ladder of civilization', and in uplifting black women in particular. ${ }^{16}$ In addition, Gaitskell's more recent work has persuasively argued that in South Africa, the women's suffrage movement was initially dominated by pro-imperial, English-speaking women and that until 1918, 'the link with Britain's empire had served more often to split than to unify white women suffragists'. ${ }^{17}$ She suggests that it was only after the First World War that 'strident Britishness was downplayed and a more determined attempt was made to draw Afrikaner women into the WEAU [Women's Enfranchisement Association of the Union]. ${ }^{18}$ As I will show here, Schreiner's letters reinforce Gaitskell's point about the divisiveness of the 'imperial tie' in the early years of the suffrage movement, and also indicate that Schreiner herself firmly believed that women's suffrage organisations should not be aligned with proimperial politics (nor the politics of Afrikaner nationalism).

In spite of the growth of scholarship concerning international women's suffrage movements, insufficient attention it seems has been paid to the links and connections between the various 'national' women's suffrage movements - not only the formal organisational links, but also the informal links forged and developed through friendship and correspondence networks which formed an important part of the fabric of the global suffrage movement. This is all the more striking considering the scholarly interest in colonial and imperial networks which has developed in the last two decades, exemplified (regarding the South African context) by the work of Alan Lester. A non-imperial exception here is the work of Mineke Bosch and Annmarie Kloosterman who have written about letters and friendship networks in the International Woman Suffrage Alliance (IWSA). They argue that these letters provide unique insights into the 'informal sisterhood of the IWSA'19 and help shed light on the transnational political networks which played a key role in shaping the IWSA's activities. Taking Bosch and Kloosterman's argument about the importance of letters in revealing the wider workings of the international women's suffrage movement as a 
starting point, in what follows I consider the political connections and tensions evident in letters written by Olive Schreiner to her friends and associates in the suffrage movement in Britain, Holland and South Africa. All of Olive Schreiner's approximately 4800 letters have recently been published in full by the Olive Schreiner Letters Project. ${ }^{20}$ Many of these previously unpublished letters shed important new light on Schreiner's life and work, and on aspects of South African - and indeed global - history. Schreiner's letters are particularly revelatory of the operations and ideologies of the suffrage movement in South Africa, and they indicate that Schreiner used her contacts in the global suffrage movement to advance local suffrage work, but they also suggest some of the key differences and disagreements between the British (and American) and South African suffrage movements, and the tensions these differences sometimes resulted in.

In her dialogue with metropolitan and local suffragists, Schreiner's emphasis was always on universal suffrage and this brought her into conflict not only with local suffrage organisations in South Africa who were willing to accept the vote on the same (racial) basis as men, but also with key figures in the global suffrage movement who in Schreiner's estimation failed to respect the local particularities of the South African context (notably Carrie Chapman Catt). Schreiner's strongly anti-imperial politics put her at odds with many feminists at the time, both in South Africa and elsewhere, for as Antoinette Burton has argued concerning the early twentieth century period, 'many middle-class British feminists were imperial in their outlook, their aspirations, and their identities. ${ }^{21}$ As I will show, Schreiner's letters complicate the history of the local South African women's suffrage movement, but also complicate the history of the wider global, metropolitan movement, and the relationship between the two. Her suffrage letters also reinforce the arguments made by Gring-Pemble about the importance of nineteenth-century women's correspondences as an arena in which women could develop an 'activist agenda' and which for individual women 'facilitated her entry into and success in the public arena'. ${ }^{22}$ While Schreiner was already very much a figure in the public arena and politically active in a range of contexts, I suggest here that her letters themselves can usefully be seen as constituting and not just facilitating or planning - political work. ${ }^{23}$ Schreiner's suffrage letters thereby also reinforce arguments made in more recent epistolary scholarship that 'the letter puts pressure on the distinction between public and private ${ }^{124}$, and the related rejection of letters as merely 'private' or 'intimate'.

\section{Olive Schreiner and Women's Suffrage in South Africa}

Olive Schreiner (1855-1920) was a South African writer, feminist and social theorist. She first came to public prominence following the publication of her novel, The Story Of An African Farm, in 1883. She spent much of the 1880s living in Britain where she was active in radical intellectual and political circles. She was a member of the Social Democratic Federation and the Men and Women's Club, and developed long-term friendships with, amongst others, 
Eleanor Marx, Karl Pearson, Edward Carpenter, Isabella Ford, and Henry Havelock Ellis. ${ }^{25}$ She returned to South Africa in 1889 and spent the next twenty four years living and working there. She was an active and vocal opponent of British imperialism in Southern Africa, and wrote and published extensively on this subject. ${ }^{26}$ It is worth noting that Schreiner first came to know Frederick Pethick-Lawrence in relation to their shared opposition to the 18991902 South African War, which as Laura Mayhall has argued, was a key moment in the development of suffrage militancy in Britain. ${ }^{27}$ After the South African War, Schreiner's political activities and writings became increasingly focused on 'the woman question', with woman's suffrage as one part of this.

The South African women's suffrage movement had its roots in the Temperance Movement, which organised the first suffrage branch in Cape Town in 1895. The first fully-fledged suffrage organisation was the Women's Enfranchisement League (WEL), with the first branch in Durban in 1902, but with branches opening in most of South Africa's major cities fairly quickly thereafter. ${ }^{28}$ Schreiner became involved with the Cape branch of the WEL around 1907, and worked to promote the cause of women's suffrage by hosting and attending 'at home' drawing room meetings, distributing pamphlets, drumming up members for the WEL, and by engaging in extensive letter-writing activities with other WEL members, attempting to influence their views, strategies and policies in 'behind the scenes' ways. However, in 1911 when the WEL came under the auspices of the national Women's Enfranchisement Association of the Union (WEAU) and its leadership made it clear that they would be campaigning for the vote on the same (racial) grounds as men nationally, Schreiner resigned. Amongst Schreiner's archived letters is her copy of a Cape WEL pamphlet which proclaimed the organisation's objective 'to promote an intelligent interest in the question of the political enfranchisement of Women in Cape Colony'. Schreiner annotated it, 'It was not a personal matter than made me leave the society The women of the Cape Colony all women of the Cape Colony These were the terms on which I joined' ${ }^{29}$ Schreiner's defence of the principle of universal suffrage within a settler colonial context is all the more remarkable given that, as Rupp has highlighted, even within the wider international suffrage movement, 'dominant cultural assumptions made the international organizations no more hospitable than national groups for women of color living in predominantly white societies. ${ }^{130}$

In spite of her formal resignation from the WEL, Schreiner continued her correspondence with many of her friends who remained active in the WEL and in some cases she tried to persuade South African friends to her point of view regarding universal suffrage. Schreiner also continued to write on the 'woman question' more generally (and for Schreiner the vote was only ever one small part of this much bigger question) and one outcome of this was the publication in 1911 of her well-known feminist treatise Woman and Labour. My main focus here ends in 1913, because it was at the end of this year that Schreiner returned to Britain where she was to remain until shortly before her death in 1920, and during this period her political interests and activities shifted focus once more, and were dominated by Schreiner's 
pacifist work following the outbreak of World War I. What then do Schreiner's letters suggest about the connections and tensions between the local South African and the wider global suffrage movements?

\section{Schreiner's letters and suffrage networks}

As I have already indicated, Schreiner's letters suggest that she was very much immersed in a global suffrage network, and that she explicitly promoted 'networking' to further suffragist work. Thus for example, in the first quotation following, Schreiner highlights to PethickLawrence that the South African movement was not operating in isolation. She comments on 'one of our Cape League' representing the suffrage cause in London who had written to Schreiner from the Bow Street Courts, and refers to the South African politician F.S. Malan speaking in support of British 'suffragettes'. She flags up these crossovers and exchanges for Pethick-Lawrence, commenting also on her niece selling suffrage materials in Trafalgar Square, and it is evident that suffrage traffic between metropole and periphery was very much two way. As Nolan and Daley have argued, 'New World suffragists of the past were engaged in a dialogue with their Old World sisters. ${ }^{131}$

It is also clear that Schreiner's connections in the global movement were crucial to sustaining her political optimism, and helping her, as she comments, to be 'content with my little narrow life here':

Its too splendid the fight our women are making. I am glad to hear one of our Cape League was with you on the 29th. Mrs G ( ) She wrote me a post card from Bow Street ... Did you get F. S. Malan's speech I sent you? It was fine how he spoke out for the Suffragettes in London, wasn't it? ${ }^{32}$

It is so splendid to think of all you are doing dear friends, it makes me content with my little narrow life here shut off from all the world to think of all you are doing; but sometimes I have a terrible wish to be among you all. A friend of mine writes she saw my niece selling papers in Trafalgar Sq. at your last big meeting. She will soon be returning to this country. I wonder if you have ever come across her. Lady Constance Lytton knows her. It doesn't matter much if you don't get the franchise at once; this fight is educating women as nothing else could; and educating the world to know what women can do. ${ }^{33}$

This notion of her wider international connections relieving her sense of literal and political isolation is further re-iterated when in 1911 Schreiner hosted the Dutch suffragist Aletta Jacobs and the American Carrie Chapman Catt, both of the IWSA, as part of their world tour. She wrote a number of letters of introduction for Jacobs to her own political contacts and friends in South Africa ${ }^{34}$, and after Jacobs' visit she wrote to her commenting, 'What a pleasure it was to me to pass that one day with you I can't tell you. You would have to realize how narrow the little woman's world still is in South Africa, to to know how it 
heartens \& joys one to meet a large, broad woman! $!^{35}$ Afterwards she maintained a correspondence with Jacobs, and in 1914 stayed with her in Holland. She was invited to attend the 1915 International Congress of Women at the Hague, organised by Jacobs, but could not attend owing to ill health. In terms of Schreiner's connections with prominent figures within the wider suffrage movement - apart from with the Pethick-Lawrences, Constance Lytton ${ }^{36}$ and Aletta Jacobs - we know too from a letter to Pethick-Lawrence that she attended a number of women's meetings once she was living in London from late 1913 on, and in 1915 went to meet personally with Sylvia Pankhurst, commenting to him, 'I went yesterday to see Sylvia Pankhurst at the East End, but she was out. ${ }^{37}$

I have already referred to the suffrage-related books Pethick-Lawrence supplied Schreiner with, and it is clear that Schreiner distributed these amongst her friends and connections in the South African suffrage movement, attempting to introduce metropolitan ideas into a movement often dominated by narrow and parochial political ideas. Indeed Schreiner attempted not only to deploy published books in this way, but at times also passed on the letters of her metropolitan suffrage movement friends in an effort to influence local suffragists, such as in the following examples to her friend Mimmie Murray ${ }^{38}$, a local South African suffragist:

Have you read a book called The Convert by Elizabeth Robins? It is on ^about^ the suffragette movement in London. Real women \& men are brought in, but there is also a mere story ${ }^{\wedge}$ part ${ }^{\wedge}$, which I think touches the question very near its root. If it were only a vote we wanted, perhaps those people would be quite right who say it is not worth suffering \& going to prison for, or even dying, if that were necessary. Its because the vote means so much more; because of the great questions of sex \& of social life lying behind that it is worth all the sacrifice we can make.

I am enclosing you a very beautiful letter I have had from a dear friend of mine Lady Constance Lytton a daughter of the Earl of Lytton the writer \& a niece of Lady Locks who once lived at the Cape. Please return it me. She was at first very much opposed to the suffragettes but is now one of their leading workers. She is one of the noblest $\&$ most beautiful women both in mind \& body that I ever met. ${ }^{39}$

Yes, make any use you like of Lady Constance Lytton's letter that you think will be useful, but don't let any of it get into print. By the post which has just come \& brought me your letter, is also one from her, very full of joy in the work \& enthusiastic love for Mrs Pethick Lawrence \& the other leaders. I do think you will be so very right in starting \& working your own society entirely unconnected with those in Cape Town. Why not ${ }^{\wedge}$ too $^{\wedge}$ call yours simply "the Woman's Association" \& make it a little broader in its scope - to take in all matters directly affecting womans position; I have resigned my position as the President of the woman's enfranchisement When I am in Cape Town I want you \& some other women such as Mrs Brown Mrs Charles Molteno, Mrs Murray, Mrs Purcell, that splendid woman Mrs Advocate de Villiers \&c to come together \& form a little 
society not at all to oppose any other woman's league but on a broader basis. But we can speak of this when we meet. ${ }^{40}$

In the first extract she comments on Robins's book and the light it shed for her on the 'Woman Question', and simply passes on Constance Lytton's letter; in the second extract she explicitly gives Murray permission to make political use of the letter, and then attempts to persuade Murray to take a broader outlook in forming a new 'Woman's Association', and was clearly 'working' her contacts in the local suffrage community to influence the formation of a women's movement 'on a broader basis'.

In spite of Schreiner's status as a highly skilled and well-connected operator in the global suffrage movement, it was in her contacts with these global figures that she stressed the importance of respecting local conditions, local circumstances, and the importance of the 'hum-drum' everyday women's movement: not the grand gestures and high-profile activism of the militant movement in Britain, but the drawing room meetings, the low-level politics of conscientising and educating women in South Africa.

This is strikingly conveyed in a 1908 letter from Schreiner to Frederick Pethick-Lawrence:

Thank you for your letter. Did I tell you dear Keir Hardie came to see us at de Aar? It was the most red-letter day in my life since you and your wife were at Hanover. We are going on with our little movement in the hum drum-way which alone is possible in a land like this. Merriman is our great obstruction in the way of getting the Franchise; and a Dutch organization called The Women's Christian Union which is dead against us \& very powerful amongst the Dutch women. If we can get the Dutch women to move, all is won. ${ }^{41}$

Although Schreiner was living in the desolate, isolated backwater dorp ${ }^{42}$ of De Aar in 1908, she was visited here by Keir Hardie, one of the founders of the British Labour Party and prominent activist for women's rights, highlighting her position as a political and literary figure of international stature. Nonetheless, 'in a land like this' Schreiner was fully aware that the only possibility was 'going on with our little movement in the hum drum-way', and her focus was resolutely on local circumstances; here on the importance of securing the support of the Dutch (later Afrikaner) women, which meant overcoming the movement's pro-imperial character at the time. I would like to focus in more detail on what this 'humdrum' movement actually entailed: what was distinctively 'local' for Schreiner about the South African suffrage movement, and what tensions did this give rise to?

\section{Tensions and differences}

In spite of her willingness to draw on global ideas and global contacts, Schreiner was adamant that local movements should be allowed to develop their own character and concerns. It appears that following her 1911 visit to South Africa with Aletta Jacobs, Carrie 
Chapman Catt wrote a letter to the leader at the time of the Cape WEL commenting critically on aspects of the WEL's strategies and activities. While the details of Catt's criticism of the WEL at this point are not clear, it is possible that she was encouraging women in South Africa to pursue the vote on the same (racial) grounds as men; this might explain Schreiner's angry response. ${ }^{43}$ Certainly Catt's ideas about suffrage were infused with social Darwinian notions of the 'evolutionary development from primitive barbarism to developed civilization', and consequently the 'issue of racial exclusion has complicated Catt's legacy'. ${ }^{44}$ Schreiner's furious account of Catt's letter to WEL president Julia Solly ${ }^{45}$, in a letter to Mimmie Murray, underlines her belief in the importance of local autonomy for political organisations:

I am sending a bit of a letter I wrote dear Anna Purcell which will explain to a little to you my attitude. I asked her to send it back that I might send it you. You know I don't sympathize with Mrs Solly's, but the letter she got was the most insolent \& conceited I ever saw written by one woman to another. Who is Mrs Catt that she dares to write so to other woman. When she has won the vote for American women I think she can come \& dictate to South Africans. If you or Mrs ?Miller had written the letter I should have said "Well they are South Africans, \& they feel all people living in one country have a right to dictate to others living in it - though I don't think so." You would imagine she was a Queen or an Empress from the way she writes! It is just like Mrs Solly might write, only conceited \& overbearing. One feels ashamed to think of such a woman. If the Queen wrote to me in such a way I should leave her letter unanswered. I do not say you are wrong my darling friend in joining in supporting the Transvaal \& Free State basis of franchise. You have your views, \& have as much right to them as I to mine; but you would never dream of writing scornfully ordering me what I was to do.

It is always such a sad thing to me, the South African women \& men too, submit to be dictated to by any one who comes from another country. The Dutch with all their faults are nobler than we English in that. [...]

I often wonder why it is that as soon as they touch public work, especially the franchise a certain class of women become so overbearing \& dictatorial. It is because a slave always tries to dominate as soon as he has a chance: He doesn't understand "freedom"!?

So for Schreiner, while she herself drew heavily on her contacts in the global suffrage movement, as I have already suggested, she also stressed that it was crucial for the women's movement in South African to develop its own independent identity and not simply emulate the tactics and ideas of the metropolitan suffragist movement in the 'colonial cringe' model. And for Schreiner, women in the suffrage movement should never dictate to one another how to manage their affairs, for each local organisation would necessarily have its own particular concerns and tactics. 
Schreiner's emphasis on the importance of local autonomy for the South African women's suffrage movement was also an expression of her belief that for the movement to be successful, it could not be exclusively pro-imperial or pro-British in character. She was strongly opposed to Irene MacFadyen holding the WEL presidency because she was simultaneously a member of the pro-imperial (and for a time anti-suffrage) Loyal Ladies League, and in a letter to Julia Solly commented, 'I really do not see that we have gained any Jingo following by having our president \& secretary both Jingoes of the Jingoes belonging to the Loyal Lady's League. ${ }^{47}$ For Schreiner, the suffrage movement should be unified and nonaligned, and she was especially anxious that South African-born and particularly Dutch and Afrikaner women should be included in its ranks. As she argued in another letter to Solly, 'it seems to me we should keep all party \& all religious differences out of any woman's Emancipation League. [...]There should be no "God save the King" or "God bless Paul Kruger"'. ${ }^{48}$ Schreiner's attempts to unite South African women anticipate the developments outlined by Gaitskell in the post-1918 period, when 'links with other [non-metropolitan] white women across the language and cultural chasm in South Africa became a greater priority to WEAU. ${ }^{49}$ The key difference, however, is that while post-1918 the WEAU attempted to foster new links with Afrikaner women, this new emphasis on women's unity did not include all South African women. For Schreiner, on the other hand, even as early as 1907,

It seems to me that a woman's suffrage society knowing nothing of party or religious or race differences \& working solely for fo woman's enfranchisement is exactly what we should have at present. Both the "Loyal Ladies League" \& the "Woman's Federation" make the suffrage one of their aims; but we want some one organization in which all women can unite. ${ }^{50}$

Thus Schreiner's efforts to rid the South African women's suffrage movement of its early narrowly pro-imperial character and to promote women's unity went a step further by explicitly including all women, 'knowing nothing of... race differences'.

For Schreiner, another distinctive feature of the local political scene in South Africa was that, unlike in Britain, women must be educated to want the vote, and for her that that education was perhaps more important even than the vote itself in conscientising and politicising women, as she stressed in letters to Pethick-Lawrence and Mimmie Murray:

When women do get the vote in England the militant movement will have been a splendid education to women as well as men and put them on quite a different footing from what they are on here and in other countries.

What we have to do here is to educate our women TO WANT IT. ${ }^{51}$

It seems to me that for the next five or eight years our work in S.A. is simple "spade" work, as it was in England 25 years ago. What we the women who desire the emancipation of all women have to do is to try to make those women who have not 
seen its importance to see it, to hold endless drawing room meetings, even if they be only meetings of 9 or 10 persons.

To try \& advance the education of all girls by all in our power: to read \& study social \& public matters ourselves, so that, when we have the vote we shall be able wisely \& independently to use it, each for those ends we think most important. The men in S.A. are much more liberal \& enlightened on the woman question than the mass of ourselves, \& it is ourselves we have to try to rouse, \& enlighten.

As soon as a very large mass of women in S.A. wish for the vote men will give it them at once. Our condition here is very different from that of women in England. ${ }^{52}$

In her comments to Murray in particular, Schreiner's reference to 'simple spade work' chimes with her comment about the 'hum-drum' local movement: Schreiner was certain that the tactics of militant suffragists in Britain were right in that context, but would be quite wrong in the South African one. She also highlights that South African men were much in advance of women on the question of women's enfranchisement, in part because of the realisation amongst Cape politicians in particular that enfranchising white women would be a way to dilute the influence wielded by the limited franchise still enjoyed by black men in the Cape at the time.

This was ultimately, for Schreiner, what defined the South African context, and ought to shape the political choices and activities women engaged in. For her, the campaign for women's suffrage should be part of a struggle for universal adult suffrage and not at odds with fight against racial oppression. She commented on this as early as 1898 , in a letter to her brother Will Schreiner: 'I am a one adult one vote man. I believe that every adult inhabiting a land irrespective of race, sex, wealth or poverty should have the vote; $\&$ that it is a power more needed by the poor, the weak, \& feeble than the wealthy or strong. ${ }^{53}$ When the women's suffrage organisations in South Africa made it clear that they would accept the vote on the same racial basis as men in the Orange Free State and Transvaal provinces, Schreiner was horrified, writing to Mimmie Murray:

I hope you understood dear, my position. I send you a bit of Earl Greys sp interview, as you may not have noticed it. You see, he feels just [page/s missing]

He thinks that terrible manhood suffrage in the Transvaal \& Freestate will hang as a millstone about the neck of the South African government; I believe it will yet bathe this land in blood, unless it is done away with. I could not do anything that would not strengthen it, as it would be strengthened if women were enfranchised the on the same evil \& rotten basis. I am for adult suffrage in all free homogenous suffrage where it means that every adult in the country will get a vote: but where it means that a tiny handful of men $\&$ women shall hold control \& government over millions, it is absolutely necessary there should be a high educational qualification. When I would fight to the last gasp to undo that manhood franchise in the Transvaal \& Freestate how can I rush to strengthen it by adding women to it? ${ }^{54}$ 
And when it became clear to Schreiner that her views about universal adult suffrage would not prevail, she became increasingly despairing about South Africa's political future, exemplified in this letter to Pethick-Lawrence, written during the negotiations which would result in the Union of South Africa in 1910:

I see from the papers that your beloved wife and Connie Lytton and other of my friends have gone to prison. How Emmeline will stand two months I don't know. I am most anxious for her health... In fighting for women we are fighting a battle in which the dawn is near. But in fighting in South Africa for justice to the native we are fighting a battle in which there is first a long dark terrible descent of years, into a depth of oppression \& wrong before the slow ascent towards better things ever begins. I don't suppose any little word of mine can be of much use: but I want to give English people a chance of seeing the other side. ${ }^{55}$

It is clear that unlike the majority of suffragists in South Africa (and more widely across the British Empire at the time), Schreiner was a supporter of both women's suffrage and the extension of political rights to 'the native'. She also presciently recognised that while the former cause was likely to be successful, especially as whites united politically and economically after 1910, that this Union of South Africa also represented a 'long dark terrible descent' for black political representation. ${ }^{56}$ But in spite of her disillusionment, Schreiner remained 'resolutely committed as ever to fighting injustice' ${ }^{57}$, with her comment about giving 'English people a chance of seeing the other side' a reference to the publication of her 1909 book Closer Union, a condemnation of the Union settlement and its implications for 'native rights'.

\section{Conclusions}

What does this examination of the connections and tensions in Schreiner's 'suffrage letters' add up to? Firstly, I suggest that Schreiner was a key figure in the South African suffrage movement who played an important role in forging political, social and intellectual links between the embryonic South African suffrage organisations and the wider global movement, and that this is something that neither Schreiner scholars nor scholars of the women's movement in South Africa have explored in great detail. In spite of her strong disapproval of the (racial) direction the South African suffrage movement ultimately took, Schreiner worked tirelessly, both through practical and epistolary means, to attempt to influence the local suffrage movement by drawing on her international links and connections. Secondly, in spite of her high-profile status and impressive international connections, Schreiner's involvement in the suffrage movement was always undertaken with a keen awareness of local conditions, in particular the political apathy of most white South African women. While she maintained close ties with many prominent figures in the international and especially British suffrage movements, and clearly took inspiration from 
some of their ideas and activities, Schreiner was acutely conscious of the need for the South African suffrage movement to be an indigenous one that could unify all women, long before the WEAU adopted its more inclusive, less imperially-minded stance after 1918. Unlike the WEAU, Schreiner was firmly convinced that women's enfranchisement should never come at the expense of (further) black disenfranchisement (although in the event this is precisely what happened). ${ }^{58}$ This is an important point for Schreiner scholarship, for contra Nadine Gordimer's assertion that, 'Schreiner seems not to have seen that her wronged sense of self, as a woman, that her liberation, was a secondary matter within her historical situation $^{59}$, Schreiner absolutely prioritised black political rights over women's emancipation. Indeed she saw the two as inextricably linked, as is very clearly apparent from her comments to Mimmie Murray in 1913:

If I get a little better I want so much to write a little letter explaining to the dear women of your union why I can't join with them great as is my sympathy with all women fighting to do away with any sex disabilities I feel so much that it is just the poorest \& most helpless women we have to fight for: not only for ourselves. In this country native $\&$ coloured women suffer much more from the mere fact they are women than we do. We who are well educated, or are rich can do much better with out the legal recognition of our state. ${ }^{60}$

Schreiner's resignation from the WEL following their decision to pursue a racial franchise, and her ongoing attempts to highlight the plight of 'native \& coloured women' provide an important counter to the depiction of Schreiner in some scholarship as narrowly concerned with 'the woman question'.

Thirdly and much more broadly, Schreiner's letters show just how important social connections, friendship and correspondence were in facilitating suffrage activities, and this suggests a fruitful area of potential additional research - that is, looking at the links between various national movements generally, and between metropolitan and colonial movements in particular. ${ }^{61}$ As Ellen Carol Dubois has argued, as scholars of women's history we should seek to uncover, 'the co-operation among women of various nations, the influence that actions of women in one country have had on those of another, and the way that women's international co-operation gave them resources to combat their marginalisation in the politics of their own nations. ${ }^{.62}$ Finally, it is worth emphasising the enormously important part played by letters in not only revealing these links and connections, but in themselves constituting these networking activities. As I have argued elsewhere with Liz Stanley, Schreiner's letters 'were often written and used as politics, rather than just being about politics'. ${ }^{63}$ Schreiner's letters thus reflect the range of ways in which she operated as a member of a local and global women's suffrage movement and the connections and tensions this gave rise to, but more than this, they are the very material of which Schreiner's political activities and networks were composed. 
${ }^{1}$ This work was supported by the Economic and Social Research Council under Grant RES-062-231286. This paper was originally presented at the 2013 Women's History Network conference on 'Women's Histories: the Local and the Global', and I am grateful to participants for their feedback and comments.

${ }^{2}$ Olive Schreiner to Frederick ('Fred') Pethick-Lawrence, 1 January 1909, UCT Manuscripts \& Archives, Olive Schreiner Letters Project transcription. All transcriptions provided replicate Schreiner's originals as closely as possible and include her mistakes, emphases, omissions, additions and deletions.

${ }^{3}$ Olive Schreiner to Frederick ('Fred') Pethick-Lawrence, 12 June 1909, UCT Manuscripts \& Archives, Olive Schreiner Letters Project transcription.

${ }^{4}$ Olive Schreiner to Frederick ('Fred') Pethick-Lawrence, 26 February 1911, UCT Manuscripts \& Archives, Olive Schreiner Letters Project transcription.

${ }^{5}$ Frederick William (Fred) Pethick-Lawrence (1871-1961) was a prominent British Labour politician His wife Emmeline (1867-1954) was a leading figure in the women's suffrage movement. Following their 1905 visit to South Africa, when the Pethick-Lawrences stayed with Schreiner for some days, a correspondence ensued between Frederick Pethick-Lawrence and Schreiner which lasted until Schreiner's death in 1920.

${ }^{6}$ Alan Lester (2001) Imperial Networks: Creating Identities in nineteenth-century South Africa and Britain London: Routledge.

${ }^{7}$ Although the article on the WSPU was planned, it was not written and did not appear in the Fortnightly Review in 1909. Schreiner's 'paper on the Woman question' later became part of her 1911 Woman and Labour.

${ }^{8}$ The books she thanks Pethick-Lawrence for included Elizabeth Robin's 1907 suffrage novel The Convert, and she later passed many of these books on to like-minded friends in South Africa.

${ }^{9}$ This paper refers to Schreiner's Closer Union, originally published as an article and then in 1909 as a book.

${ }^{10}$ While at the time the Cape franchise was non-racial (although subject to educational and property qualifications), the franchise in the rest of South Africa (Natal, Orange Free State and Transvaal) was reserved exclusively for white men. It was the extension of this racially-determined franchise to white women that Schreiner opposed.

${ }^{11}$ June Hannam (2005) International Dimensions of Women's Suffrage: 'at the crossroads of several interlocking identities', Women's History Review 14/3 \& 4, p. 543.

${ }^{12}$ Melanie Nolan and Caroline Daley (eds) (1994) Suffrage and Beyond: International Feminist Perspectives Auckland: Auckland University Press; Leila J. Rupp (1997) Worlds of Women: The Making of an International Women's Movement Princeton: Princeton University Press; June Hannam, Katherine Holden and Mitzi Auchterlonie (2000) International Encyclopaedia of Women's Suffrage Santa Barbara, Calif. ABC-CLIO Ltd; Irma Sulkunen, Seija-Leena Nevala-Nurmi and Pirjo Markkola (eds) (2009) Suffrage, Gender and Citizenship: International Perspectives on Parliamentary Reforms Newcastle: Cambridge Scholars. 
${ }^{13}$ Melanie Nolan and Caroline Daley (1994) 'International Feminist Perspectives on Suffrage: An Introduction' in their Suffrage and Beyond: International Feminist Perspectives Auckland: Auckland University Press, p. 2.

${ }^{14}$ Cherryl Walker (1990) 'The Women's Suffrage Movement: The Politics of Gender, Race and Class' in Walker, Cherryl (ed) Women and Gender in Southern Africa to 1945 Cape Town: David Philip, pp. 313-345; Pamela Scully (2000) 'White maternity and black infancy: the rhetoric of race in the South African women's suffrage movement, 1895-1930' in lan Christopher Fletcher; Philippa Levine \& Laura E. Nym Mayhall (eds) Women's Suffrage in the British Empire, Citizenship, Nation and Race London: Routledge, pp. 68-83; Deborah Gaitskell (2002) The Imperial Tie: Obstacle or Asset for South Africa's Women Suffragists before 1930?, South African Historical Journal 47, pp. 1-23.

${ }^{15}$ That is, to the Transvaal, Orange Free State and Natal.

${ }^{16}$ Scully 'White Maternity', p. 77.

${ }^{17}$ Gaitskell 'The Imperial Tie', p. 2.

${ }^{18}$ Gaitskell 'The Imperial Tie', p. 2.

${ }^{19}$ Mineke Bosch and Annemarie Kloosterman (eds) (1990) Politics and Friendship: Letters from the International Woman Suffrage Alliance, 1902-1942 Columbus: Ohio State University Press, p. 22.

${ }^{20}$ See www.oliveschreiner.org

${ }^{21}$ Antoinette Burton (1991) The Feminist Quest for Identity: British Imperial Suffragism and "Global Sisterhood" 1900-1915, Journal of Women's History, 3/2, p. 17.

${ }^{22}$ Lisa M. Gring-Pemble (1998) Writing Themselves into Consciousness: Creating a Rhetorical Bridge Between the Public and Private Spheres, Quarterly Journal of Speech 84, p. 42.

${ }^{23}$ As I have argued elsewhere regarding Schreiner's wider political involvements; see Liz Stanley, Andrea Salter and Helen Dampier (2013) Olive Schreiner, Epistolary Practices and Microhistories: A Cultural Entrepreneur in a Historical Landscape, Cultural and Social History 10/4, pp. 577-597.

${ }^{24}$ Amanda Gilroy and W.M. Verhoeven (2000) 'Introduction', in their Epistolary Histories: Letters, Fiction, Culture Virginia: University of Virginia Press, p. 21.

${ }^{25}$ On Schreiner's life and political activities see: Carolyn Burdett (2001) Olive Schreiner and the Progress of Feminism: Evolution, Gender, Empire Basingstoke: Palgrave; Ruth First and Ann Scott (1980) Olive Schreiner London: Women's Press; Anne McClintock (1995) Imperial Leather: Race, Gender and Sexuality in the Colonial Conquest London: Routledge; Karel Schoeman (1991) Olive Schreiner, A Woman in South Africa, 1855-1881 Johannesburg: Jonathan Ball Publishers; Karel Schoeman (1992) Only an Anguish to Live Here: Olive Schreiner and the Anglo-Boer War 1899-1902 Cape Town: Human \& Rousseau; Liz Stanley (2002) Imperialism, Labour and the New Woman: Olive Schreiner's Social Theory Durham, UK: sociologypress.

${ }^{26}$ Olive Schreiner (1896) The Political Situation London: Unwin; Olive Schreiner (1897) Trooper Peter Halket of Mashonaland: Unwin; Olive Schreiner (1899) An English South African's View of the Situation London: Hodder and Stoughton; Olive Schreiner (1909) Closer Union London: Fifield. 
${ }^{27}$ Laura E. Nym Mayhall (2000) 'The South African War and the origins of suffrage militancy in Britain, 1899-1902' in lan Christopher Fletcher; Philippa Levine \& Laura E. Nym Mayhall (eds)

Women's Suffrage in the British Empire, Citizenship, Nation and Race London: Routledge, pp. 3-17.

${ }^{28}$ Walker 'The Women's Suffrage Movement', pp. 324-5.

${ }^{29}$ Olive Schreiner to Unknown, January 1912, NLSA Cape Town, Special Collections, Olive Schreiner Letters Project transcription.

${ }^{30}$ Rupp Worlds of Women, p. 73.

${ }^{31}$ Nolan and Dolan 'International Feminist Perspectives ', p. 6.

${ }^{32}$ Olive Schreiner to Frederick ('Fred') Pethick-Lawrence, 22 July 1909, UCT Manuscripts \& Archives, Olive Schreiner Letters Project transcription.

${ }^{33}$ Olive Schreiner to Frederick ('Fred') Pethick-Lawrence, August 1910, UCT Manuscripts \& Archives, Olive Schreiner Letters Project transcription.

${ }^{34}$ The letters of introduction were to Isie Smuts, wife of the South African politician Jan Smuts, and to Mary Sauer, wife of Paul Sauer, acting Prime Minister of South Africa in 1911. Isie Smuts and Mary Sauer were both close friends of Schreiner's at different times.

${ }^{35}$ Olive Schreiner to Aletta Jacobs, 4 April 1911, Aletta, International Archives for the Women's Movement, Amsterdam, Olive Schreiner Letters Project transcription.

${ }^{36}$ Constance Lytton (1869-1923) was an active supporter of the WSPU, and a close friend of Schreiner's. Schreiner dedicated her 1911 Woman and Labour to Constance Lytton.

${ }^{37}$ Olive Schreiner to Frederick ('Fred') Pethick-Lawrence, May 1915, UCT Manuscripts \& Archives, Olive Schreiner Letters Project transcription.

${ }^{38}$ Mimmie or Minnie Murray nee Parkes (1865-1929) was active in the women's suffrage movement and instrumental in establishing a branch of the Women's Enfranchisement League at Graaff-Reinet.

${ }^{39}$ Olive Schreiner to Minnie or Mimmie Murray nee Parkes, 19 January 1909, National English Literary Museum, Grahamstown, Olive Schreiner Letters Project transcription.

${ }^{40}$ Olive Schreiner to Minnie or Mimmie Murray nee Parkes, 7 February 1909, National English Literary Museum, Grahamstown, Olive Schreiner Letters Project transcription.

${ }^{41}$ Olive Schreiner to Frederick ('Fred') Pethick-Lawrence, 27 February 1908, UCT Manuscripts \& Archives, Olive Schreiner Letters Project transcription.

${ }^{42}$ Small, provincial South African village.

${ }^{43}$ Scully suggests that the union of South African women's suffrage organisations in 1911 under the banner of the Women's Enfranchisement Association of the Union (WEAU) was in part a response to Catt's 'encouragement', so it is possible that her comments were focused on this issue. See Scully 'White Maternity', p. 73. 
${ }^{44}$ Kevin S. Amidon (2007) Carrie Chapman Catt and the Evolutionary Politics of Sex and Race, 18851940, Journal of the History of Ideas 68/2, p. 307; p. 309.

${ }^{45}$ Julia Solly nee Muspratt (1862-1953) was active in feminist and temperance circles, and from 1913 a member National Council of Women and later one of its vice-presidents. See R.R. Langham-Carter (1981) 'Solly, Julia Frances' in C.J. Beyers (ed) Dictionary of South African Biography Vol IV Pretoria: Human Sciences Research Council, p. 589.

${ }^{46}$ Olive Schreiner to Minnie or Mimmie Murray nee Parkes, January 1911, National English Literary Museum, Grahamstown, Olive Schreiner Letters Project transcription.

${ }^{47}$ Olive Schreiner to Julia Solly nee Muspratt, 6 April 1908, UCT Manuscripts \& Archives, Olive Schreiner Letters Project transcription.

${ }^{48}$ Olive Schreiner to Julia Solly nee Muspratt, 7 May 1907, UCT Manuscripts \& Archives, Olive Schreiner Letters Project transcription. Paul Kruger (1825-1904) was the last president of the Transvaal, one of the independent Boer Republics defeated by Britain in the 1899-1902 South African War.

${ }^{49}$ Gaitskell 'The Imperial Tie', p. 22.

${ }^{50}$ Olive Schreiner to Julia Solly nee Muspratt, 26 March 1907, UCT Manuscripts \& Archives, Olive Schreiner Letters Project transcription.

${ }^{51}$ Olive Schreiner to Frederick ('Fred') Pethick-Lawrence, May 1910, UCT Manuscripts \& Archives, Olive Schreiner Letters Project transcription.

${ }^{52}$ Olive Schreiner to Minnie or Mimmie Murray nee Parkes, 25 April 1912, National English Literary Museum, Grahamstown, Olive Schreiner Letters Project transcription.

${ }^{53}$ Olive Schreiner to William Philip ('Will') Schreiner, 12 June 1898, UCT Manuscripts \& Archives, Olive Schreiner Letters Project transcription.

${ }^{54}$ Olive Schreiner to Minnie or Mimmie Murray nee Parkes, 3 November 1912, National English Literary Museum, Grahamstown, Olive Schreiner Letters Project transcription. The reference to the 'manhood franchise' in the Transvaal and Orange Free State provinces was to the provision of the franchise to white men only.

${ }^{55}$ Olive Schreiner to Frederick ('Fred') Pethick-Lawrence, 4 March 1909, UCT Manuscripts \& Archives, Olive Schreiner Letters Project transcription. The 'little word' Schreiner refers to here is her 1909 Closer Union.

${ }^{56}$ The Union was between the British colonies of the Cape and Natal, and the former Boer Republics of the Transvaal and the Orange Free State. Schreiner was referring to that fact that the Union constitution made no provision for the extension of the Cape's non-racial, qualified franchise to the other three provinces.

${ }^{57}$ Burdett Olive Schreiner, p. 176.

${ }^{58}$ When white women in South Africa were finally enfranchised in 1930 with the passing of the Women's Enfranchisement Act, this was primarily aimed at undermining the qualified franchise for 
African men in the Cape Colony. This was followed in 1931 by the removal of the property and educational franchise qualifications for white men in the Cape.

${ }^{59}$ Nadine Gordimer (1980) 'The Prison-House of Colonialism' reprinted in her (2010) Telling Times: Writing and Living, 1954-2008 London: Bloomsbury, p. 333.

${ }^{60}$ Olive Schreiner to Minnie or Mimmie Murray nee Parkes, April 1913, National English Literary Museum, Grahamstown, Olive Schreiner Letters Project transcription.

${ }^{61}$ For a recent example of work in this area see Tara M. McCarthy (2014) Woman Suffrage and Irish Nationalism: Ethnic Appeals and Alliances in America, Women's History Review 23/2, pp. 188-203.

${ }^{62}$ Ellen Carol Dubois (1994) 'Woman Suffrage Around the World: Three Phases of Suffragist Internationalism' in Nolan and Daley Suffrage and Beyond, p. 254.

${ }^{63}$ Liz Stanley \& Helen Dampier (2012) 'I just express my views \& leave them to work': Olive Schreiner as a Feminist Protagonist in a Masculine Landscape with Figures, Gender \& History 24/3, p. 682. 